\title{
メラミン硬化型塗膜の鉄粉付着性におよぼす 温度，湿度の影響
}

(1991 年 5 月 2 日受理)

山中 雅 彦*井上由 美江

メラミン硬化型塗膜の鉄粉付着性におよぼす温度，湿度の影響について検討した。その結果，鉄粉は， 高温高湿度下で塗膜に付着することがわかった。また，鉄粉が付着した塗膜の断面を光学顕微鏡で観察 した結果，鉄粉は，塗膜内部に刺さっているのではないことがわかった。さらに，塗膜の水蒸気透過度 と鉄粉付着性との関係について検討した結果，鉄粉の付着程度が極大になる時間は，水蒸気透過度が大 きい塗膜ほど短いことがわかった。

よって，塗膜への鉄粉付着は，鉄粉が，温度および湿度の影響で酸化され，酸化された鉄粉が，水に 溶解し，塗膜に浸透することにより生じると推定できる。

\section{1 緒言}

著者らは，自動車用塗膜の性能におよ注す污染物質の影響につ いて検討している。污染物質は，塗装前の基材，㳊膜形成時の塗 嗼, 乾燥塗膜に付着あるいは混在することで塗膜品質に悪影響を およぼす。前報1では，研磨などにより損傷を受けた際に顔料が 悦落し，熱で軟化した叙膜の孔に雨などの水分に溶けた大気中の ちりが付着し発生する白系塗膜の損傷部污染について報告した。 また，クロムめっき表面を洗浄した際に洗浄水中の無機塩が残存 した場合，叙膜の密着性が低下することについて報告した213。

本報では, メラミン硬化型塗膜の鉄粉付着性に㧍よ注寸温度お よび湿度の影響について検討した結果を報告する。

\section{2 実験}

\section{1 塗板の作製}

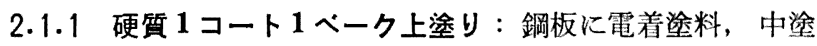
り塗料を塗装および強制乾燥後, ホワイト塗色の上叙りを勧装し,

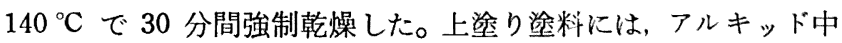
にヤシ油 $20 \%$ を含むアルキッドメラミン系塗料を顔料重量/バ インダー固形分重量 $(\mathrm{P} / \mathrm{B})=1$ に調製して用い, 叙布厚みは 40 $\mu \mathrm{m}$ とした。

なお， 1 コート 1 ベーク上鉒りとは, 上塗り塗膜が一層から成 り，一度の強制乾燥で签膜を形成させる叙嗼構成を言う。

2.1 .2 硬罂 2 コート 1 ベーク上叙り：鋼板電着塗料, 中染 り淮料を叙装打よび強制乾燥後， $\mathrm{P} / \mathrm{B}=1$ に調製したホワイト塗 色のベースコート $(15 \mu \mathrm{m})$, 次いでクリヤーコート $(35 \mu \mathrm{m})$ を

日産自動車株式会社，材料実験部，243-01 厚木市岡津古 久 $560-2$

1）山中雅彦, 色材，63，470(1990).

2）山中雅彦，菊川哲郎，志智堆之，有田雅睛，石渡秦文， 三上正道, Chem. Express, 5, 609(1990).

3）山中雅彦, 日化, 投稿中.

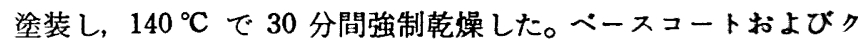
リヤーコートは,アクリルメラミン系登料を用いた。

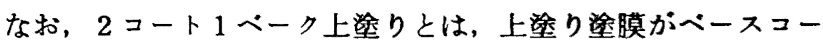
トとクリヤーコートの二層から成り，ベースコート勧装後強制乾 燥しないでクリヤーコートを塗装し強制乾燥することで塗膜を形 成させる塗膜構成を言う。

2.1 .3 軟質 1 コート 1 ベーク上染り：ポリプロピレン基村に ポリオレフィン系下染り塗料を塗装後，ホワイト叙色の上重り

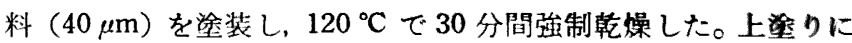
は， $\mathrm{P} / \mathrm{B}=1$ に調製したアクリルメラミン系塗料を用いた。

2.1 .4 軟翼 2 コート 1 ベーク上染り：ポリプレピレン基村に ポリオレフィン系下叙りを鉒装後， $\mathrm{P} / \mathrm{B}=1$ に調製したホワイト 塑色のベースコート $(15 \mu \mathrm{m})$, 次いでクリヤーュート $(35 \mu \mathrm{m})$

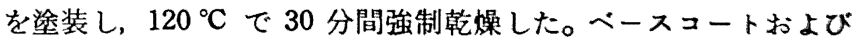
クリヤーコートには, アクリルメラミン系垶料を用いた。

\section{2 試験方法}

$70 \mathrm{~mm} \times 150 \mathrm{~mm}$ の大きさの各種垐板に, 粒径 $75 \sim 105 \mu \mathrm{m}$ の 鉄粉を $17 \mathrm{mg}$ 散布した。散布方法としては，鉄粉を 200 ィッシ ュのふるいにかけふふるいを通過しなかった鉄粉を 150 ィッシ ニのふるいにかけながら塗板上に均一に散布されるように行っ た。この塗板を水平にして, 温度を $20 ， 30 ， 50^{\circ} \mathrm{C}$ ，あるいは $80{ }^{\circ} \mathrm{C}$ に，また相対湿度を $50 、 73 \%$ ，ちるいは $95 \%$ に調節した 桓温佰湿室に，8，15，24 時間，あるいは48 時間放淦した。

\section{3 鉄粉付着基の解析}

試験終了後刷毛ではき，画像解析装履(ニコレ製イィージフナ

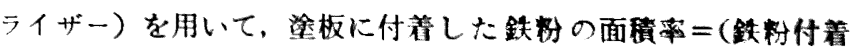

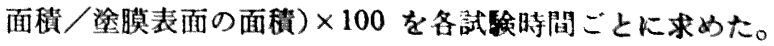

\section{4 水蒸気透週度の測定}

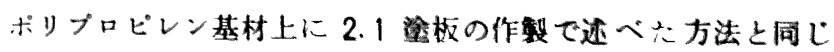

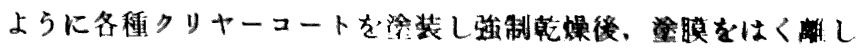
遊離鉒瞙を作製した。 
JISZ 0208 の透㳑カップに $\mathrm{CaCl}_{2}$ を $5 \mathrm{~g}$ 入れ，遊離塗膜をカッ ブにセットし, 温度を $50 \mathrm{C}$, 相対湿度を $95 \%$ に調節した恒温恒 湿室に $0 ４ ４ ８ ， 12 ， 24$ 時間放置した。各時間での $\mathrm{CaCl}_{2}$ の吸水 量を測主さし、クラフ化した直線の傾きを上塗りの膜厚で割ること により, 水蒸気透過度を求めた。

\section{5 模かけ密度の測定}

ポリブロビレン基材に各種塗料を乾燥塗膜厚が $50 \mu \mathrm{m}$ になる よらに症装し強制乾嬠した。次に，塗膜をはく離し，(株)東洋ボ ールドウィン製の動的粘弾性自動測定機を用いて塗膜の動的粘弾 性を测定した。橋かけ密度は415)，粘弾性測定結果を用いて，E= $3 n R T^{6)}$ ( $E$ : Young 率, $n:$ 橋加密度, $R:$ 気体定数, $T:$ 絶対 温度）から求めた。

\section{3 結果と考察}

拣験に用いた上塗り塗膜の物珄を表 1 に示した。表 1 の硬質 2 コート1ペークメラミン硬化型塗膜の鉄粉付着性におよぽす温度 および湿度の影嘌について検討した。表 2 から, 塗膜への鉄粉付 着は, 温度および湿度の両因子により生じ, 高温高湿度下で生じ やすいことがわかった。そこで, 表 1 に示した 4 種類の塗膜を用

Table 1 Physical properties of coating film

\begin{tabular}{cccc}
\multicolumn{2}{c}{ Hardness } & $T_{\mathrm{g}} /{ }^{\circ} \mathrm{C}^{c)}$ & $\begin{array}{c}\text { Cross-linking density/ } \\
\mathrm{mol} \cdot \mathrm{ml}^{-1}\end{array}$ \\
\hline $2 \mathrm{C} 1 \mathrm{~B}^{a)}$ & Hard & 88 & $1.9 \times 10^{-3}$ \\
& Sof $\mathrm{t}$ & 52 & $0.75 \times 10^{-3}$ \\
$1 \mathrm{C} 1 \mathrm{~B}^{b)}$ & Hard & 80 & $2.9 \times 10^{-3}$ \\
& Sof t & 66 & $1.5 \times 10^{-3}$
\end{tabular}

a) 2 coat 2 bake.

b) 1 coat 1 bake.

c) Glass-trensition temperature.

Table 2 Effect of temperature and humidity to iron powder adhesion on coating film

\begin{tabular}{cccccc} 
& & \multicolumn{4}{c}{ Temperature $/{ }^{\circ} \mathrm{C}$} \\
\cline { 5 - 6 } Humidity/\% & Time/h & 20 & 30 & 50 & 80 \\
\hline 50 & 8 & no & no & no & no \\
& 15 & no & no & no & no \\
& 24 & no & no & no & no \\
& 48 & no & no & no & no \\
73 & 8 & no & no & no & no \\
& 15 & no & no & no & no \\
& 24 & no & no & no & no \\
& 48 & no & no & no & no \\
95 & 8 & no & no & yes & yes \\
& 15 & no & no & yes & yes \\
& 24 & no & no & yes & yes \\
& 48 & no & no & yes & yes
\end{tabular}

no: Adhesion did not occur.

yes : Adhesion occurred.

4) L. E. Nielsen, J. Macromol. Sci., -Rev. Macromol. Chem., C 3[1], 69(1969).

5) 中道敏应，色材，57，643(1984).

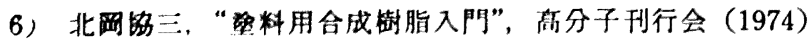
p. 74 .

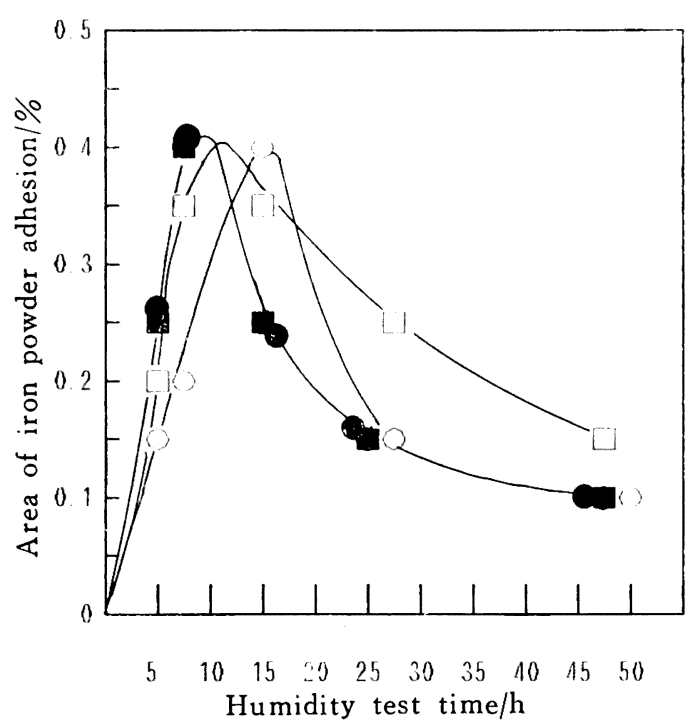

Fig. 1 Relation between humidity test time and area of iron powder adhesion on coating film

O : 1 C 1 B-hard, $\square: 2$ C 1 B-hard, $: 1 \mathrm{C} 1 \mathrm{~B}$-soft, $: 2 \mathrm{C} 1 \mathrm{~B}-\mathrm{sof} \mathrm{t}$

いて, 温度が $50{ }^{\circ} \mathrm{C}$ で相対湿度が $95 \%$ の条件下における鉄粉付 着面積率と試験時間との関係について検討した。図 1 から，鉄粉 付着面積率は, 試験時間とともに増大し, ある時間で極大とな り，それ以上時間が経過すると低下することがわかった。ある試 験時問より鉄粉付着面積率が低下するのは，鉄粉が内部まで酸化 され，もろくなり，刷毛ではく際に鉄粉が脱落するためであろう と推定できる。また, 鉒膜種によって付着面積率が極大值をとる 時間が異なるのは, 鉄粉の塗膜への付着速度の違いにより生じる と推定できる。

次に, 鉄粉の塗膜への付着状況を知るために, 鉄粉が付着した 箇所の塗膜断面を光学顕微鏡で観察した。図 2 は, 硬質 2 コート 1 ペーク上塗り塗膜, 図 3 は, 軟質 1 コート 1 ベーク上叙り塗膜 に鉄粉が付着した筒所の叙膜断面を示したものである。図 $2 ， 3$ から，鉄粉は，鉄粉の荷重および温度による塗膜の軟化により， 塗膜内部に刺さっているのではなく，塗膜表面上に接しているこ とがわかった。

よって，塗膜への鉄粉付着は，塗膜に散布された鉄粉が，温度 および湿度の影薌で鉄粉の外辺部から水酸化鉄(III) になり，こ の水酸化鉄 (III) が，水分により溶解され，温度の影響で塗膜中に 浸透し，次いで，鉒膜中に水分が拡散することにより生じると考 えられる。

上記鉄粉付着機構から，鉄粉の叙膜への付着性は，水分の叙膜 への浸透性 ${ }^{718)}$ が大きく寄与していると推定できる。そこで，叙膜 への水蒸気透過度と鉄粉付着性との関係について検討した。4 種 類の上塗り笙膜における水蒸父透過量と時間との関係を図 4 に示 した。図 4 から, 水蒸気透過量は, 時間と正比例の関係にあり, 勾配は，签膜の種類により異なっていることがわかった。公邽 は, 1 洔間当たりの水蒸気透過量であり, 上塗り塗膜の水蒸父洴

7）三原一幸, “解説 塗料学”, 理工出版社 (1975) p. 433 .

8）井本 稳, 大塚好治, 大藤能親, 小川雅弥, 川口佮一, 黑谷壽雄, “新化学序説”, 化学同人 (1973) p. 80. 


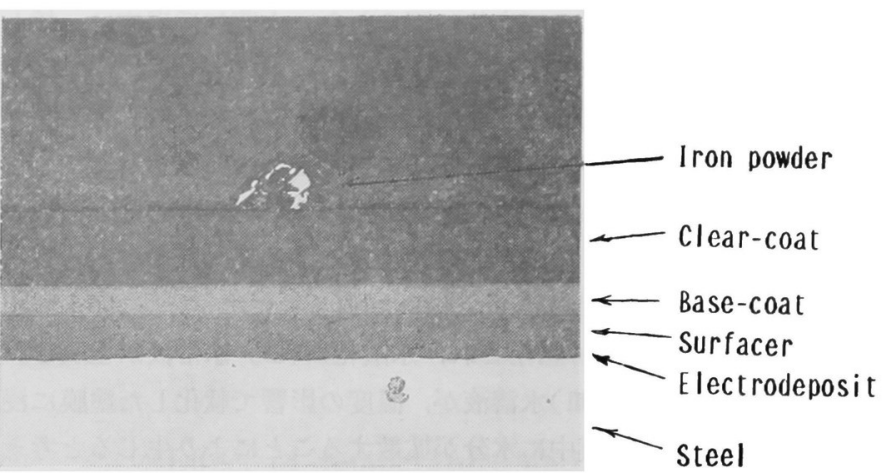

$\times 100$

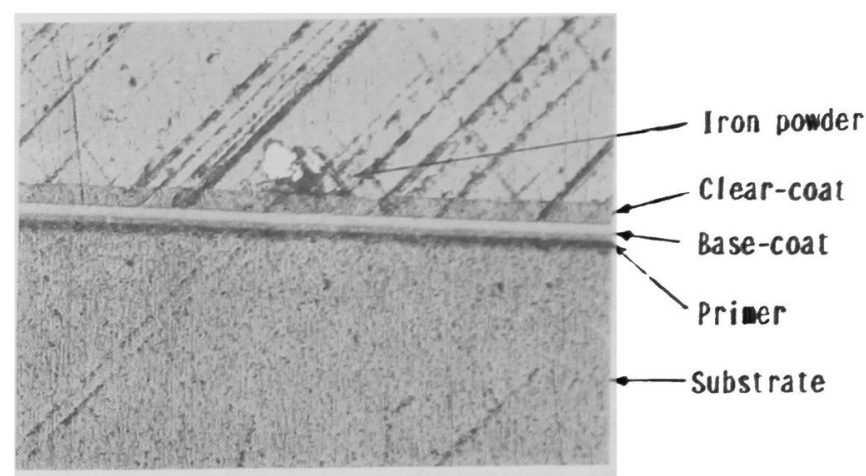

$\times 100$

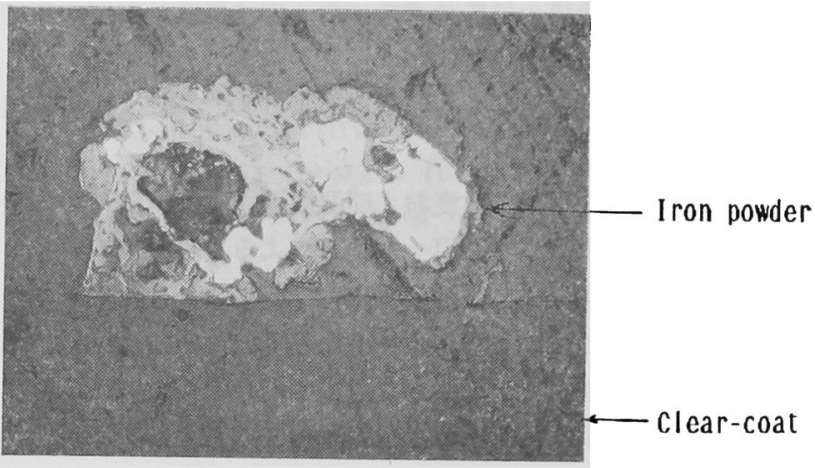

$\times 400$

Fig. 2 Microphotograph of the section of 2-coat-1-bake hard coating film focused on the iron adhesion part

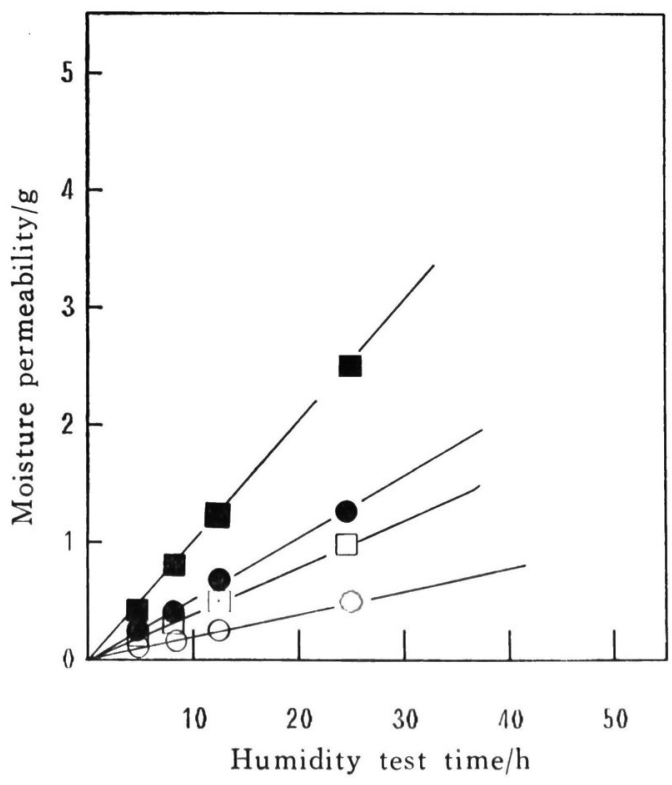

Fig. 4 Relation between humidity test time and moisture permeability

: 1 C 1 B-hard, $\square: 2$ C 1 B-hard,

: $2 \mathrm{C} 1 \mathrm{~B}-\mathrm{sof} t$

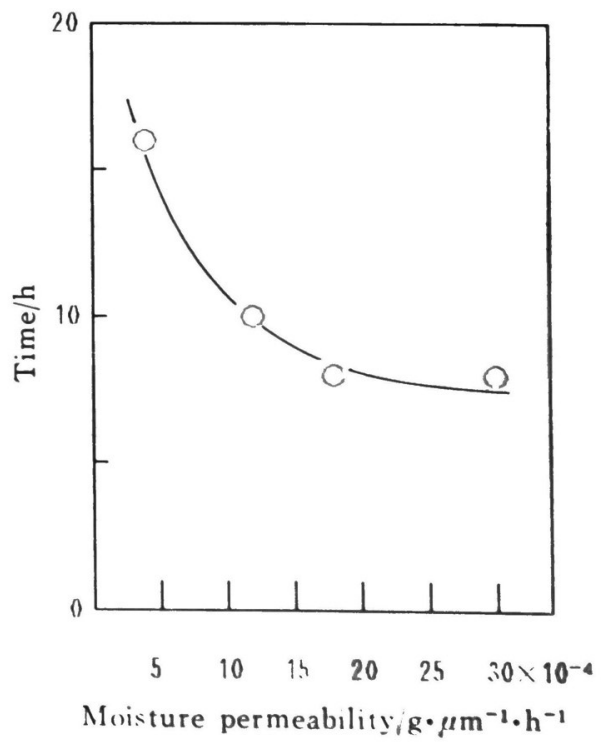

Fig. 5 Relation between moisture permeability and time to reach maximum adhesion of iron powder 
$\times 10^{-4}$

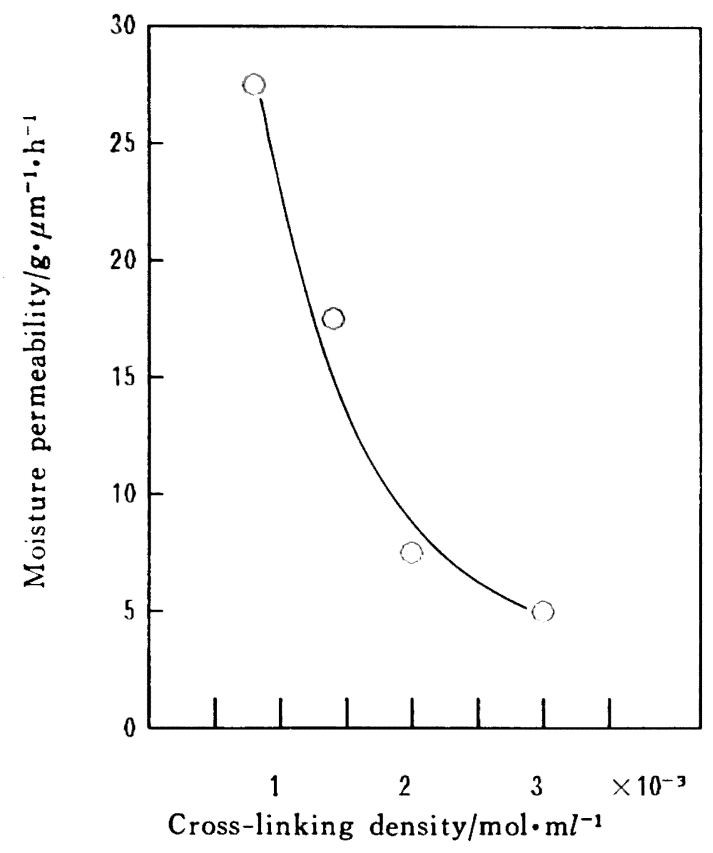

Fig. 6 Relation between cross-linking density and moisture permeability

過度を示している。次に, 塗膜の水蒸気透過度と鉄粉付着性との 関係について検討した。四 5 に，水蒸気透過度と鉄粉付着面積率 が極大となるときの時間との関係を示した。図 5 から, 水蒸気透 過度が大きいほと，鉄粉付着面積率の極大になる時間が短く，水 蒸気透過度が $18 \times 10^{-4} \mathrm{~g} \cdot \mu \mathrm{m}^{-1} \cdot \mathrm{h}^{-1}$ 以上では, 一定值を示すこと がわかった。整膜種により水蒸気透過度が巽なるのは, 主に, 塗 膜のガラス転移点および橋かけ密度の違いによるものであると考 之られるが, 本論文に用いた塗膜のガラス転移点は, 表 1 に示し たよらに水蒸気透過度測定温度より高いため, 橋かけ密度による 影需が大きいと考えられる。四6は, 橋かけ密度と水蒸気透過度
との関係を示したものである。図 6 から, 水蒸気透過度は, 橋か け密度が高くなるほど低下している。

上って，鉄粉付着性は，泾膜の水蒸気透過度に上り影響され， 水蒸気透過度が小さいほど低下する。また, 水蒸気透過度は, 憍 かけ密度と関係があり，橋かけ密度が高いほど低下する。

以上の結果から，塗膜への鉄粉付着は，塗膜㳻布された鉄粉 が，温度および湿度の影響で水酸化鉄(III)になり，この水酸化 鉄(III) が水分に上り溶解され，水酸化鉄(III) 水溶液が生成され る。この水酸化鉄 (III)水溶液が，温度の影響で軟化した㳊膜に浸 透し，次いで，塗膜中に水分が払散することにより生じると考え られる。

また，鉄粉付着率は，刻膜の水蒸気透過度の寄与が大きく，橋 かけ密度を高くすることにより低下させることができる。

\section{4 結 論}

メラミン㹬化型叙膜の鉄粉付着珄におよぼす温度，湿度の影㢸 について検討した結果，以下に示す結論を得ることができた。

（1）鉄粉付着は, 温度および湿度により影響され，高温高湿 度下で生じる。

（2）鉄粉付着機構は，温度および湿度の影響で，鉄粉から生 じる水酸化鉄 $(\mathrm{III})$ 水溶液の塗膜への浸透によるものである。

（3）鉄粉付着状況は，鉄粉の荷重拈よび塗膜の軟化に上り塗 膜に刺さっているのではなく，染膜中に浸透した水酸化鉄(III) が，塗膜表面上の鉄粉と結合してくさびの役目を果たしている。

（4）鉄粉付着率は, 染膜の水蒸気透過度汇上り影響され, 水 蒸気透過度が大きいほど高くなる。

（5）鉄粉付着は，鉒膜の橋かけ密度が高い汪ど低下寸る。叙 膜の使用される環境温度が, ガラス転移点より高い場合には, ガ ラス転移点についても考感する必要がある。

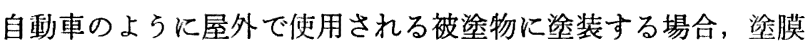
の橋か壮密度を高くすることで，工場などから放出される鉄粉の 付着を低減させることができる。 


\section{Effect of Temperature and Humidity on Iron Powder Adhesion of Melamine-cured Coating Film}

Masahiko Yamanaka* and Yumie InOUE

Materials Experiment Department, Materials Research Laboratory, NISSAN motor

Co. Ltd.; 560-2, Okatsukoku, Atsugi-shi 243-01 Japan

Effect of temperature and humidity on the adhesion of iron powder onto melamine-cured coating film was discussed. Iron powder adhesion occurred under high temperature and humidity. From the result of the observation of the coating film section with a microscope, it was found that the film was not stuck by iron powder, but the powder adhered on the film surface.

The relation between iron powder adhesion and the moisture permeability of film was discussed for the top-coat. From the result it was found that iron powder adheres easily to coating film having high moisture permeability. Moisture permeability was affected by the cross-linking density of film, and the film with lower cross-linking density resulted in much adhesion of iron powder.

It was thought that iron powder adhesion occurred by the penetration of $\mathrm{Fe}(\mathrm{OH})_{3}$ aqueous solution to coating film under high temperature and humidity. 